\title{
Aristides Leão: a birth centennial homage with comments on his spreading depression
}

\author{
Aristides Leão: homenagem ao centenário de nascimento com comentários sobre sua \\ depressão alastrante
}

Eliasz Engelhardt' ${ }^{1}$ Marleide da Mota Gomes²

\begin{abstract}
The year of 2014 is the birth centenary of Aristides Azevedo Pacheco Leão (1914-1993), and also marks seventy years of the publication of his discovery of the novel electrophysiological phenomenon, named by him “spreading depression"(SD), soon designated "Leão’s wave" or “Leão's spreading depression". This was a remarkable scientific milestone, and the author must be celebrated for this achievement, as the studies he triggered proceeded worldwide, with new concepts, as spreading depolarization, until the present days. Robust experimental and clinical evidence emerged to suggest that these and related electrophysiological phenomena are involved in the mechanisms of migraine aura, acute cerebrovascular diseases, traumatic brain injury, transient global amnesia, epileptic seizures, and their pathophysiological characteristics come to offer new therapeutic perspectives. He was a remarkable and complex personality, and the authors remit the readers to a paper where his personal life is contemplated.
\end{abstract}

Keywords: Aristides Leão, neurophysiology, spreading depression, migraine, cerebrovascular diseases, seizures.

\begin{abstract}
RESUMO
O ano de 2014 é o centenário de nascimento de Aristides Azevedo Pacheco Leão (1914-1993), e também assinala setenta anos da publicação de sua descoberta, que ele denominou "depressão alastrante" (DA), logo designada "onda de Leão" ou "depressão alastrante de Leão". Foi um notável marco científico e o autor deve ser celebrado por esse feito, considerando que estudos que desencadeou continuaram no mundo todo, com novos conceitos, como a despolarização alastrante, até os dias atuais. Evidência experimental e clínica robusta emergiram sugerindo que esses fenômenos eletofisiológicos e outros relacionados encontram-se envolvidos nos mecanismos da aura da enxaqueca, doenças cerebrovasculares agudas, lesão cerebral traumática, amnésia global transitória, crises epiléticas, sendo que suas características fisiopatológicas vêm oferecer novas perspectivas terapêuticas. Foi uma personalidade complexa e notável, e os autores remetem os leitores para um artigo no qual sua vida pessoal é contemplada.
\end{abstract}

Palavras-chave: Aristides Leão, neurofisiologia, depressão alastrante, enxaqueca, doenças cerebrovasculares, epilepsia.

The year of 2014 is the time to commemorate the birth centennial of Aristides Azevedo Pacheco Leão (August $3^{\text {rd }}$, 1914 - December $14^{\text {th }}, 1993$ - born in Rio de Janeiro, deceased in São Paulo, and buried in Rio de Janeiro, according information of the widow, Mrs. Elisabeth Raja Gabaglia Leão) ${ }^{1}$.

This paper intends to present some facets of Aristides Leão's early academic formation, his scientific achievements, and some of their unfoldings.

He ingressed in the School of Medicine of Sao Paulo (1932). However, while in the $2^{\text {nd }}$ year, he interrupted the course due to a physical ailment. On recovering he decided to be a researcher. He left to the US (1941), being admitted in the Medical Science Department (Physiology) of Harvard University. There, he achieved the degrees of MA (1942), and $\mathrm{PhD}(1943)^{1,2,3}$. In the same year he became a Research Fellow of the Department of Anatomy at the Harvard Medical School. Despite the opportunity to remain in the US and develop further his studies, he opted to return to Brazil ${ }^{2,3}$.

Back to Brazil (1944), Aristides Leão was invited by Carlos Chagas Filho to compose the basic staff of the Institute of Biophysics he was structuring. He was immediately joined by Gustavo de Oliveira Castro and Romualdo José do Carmo, and soon also by Hiss Martins-Ferreira ${ }^{2,3,4}$ (Figure 1).

Aristides Leão, besides his career as neurophysiologist, reached top administrative positions: Director (1966-1970) and Chief emeritus of the Department of Neurobiology (IBCCF) (1984-1993), and President (1966-1981) and President emeritus (posthumous) (1994) of the Brazilian Academy of Science,

${ }^{1}$ Universidade Federal do Rio de Janeiro, Setor de Neurologia Cognitiva e do Comportamento, Instituto de Neurologia Deolindo Couto e Centro de Doença de Alzheimer-Instituto de Psiquiatria, Rio de Janeiro RJ, Brazil;

${ }^{2}$ Universidade Federal do Rio de Janeiro, Programa de Epilepsia, Instituto de Neurologia Deolindo Couto, Faculdade de Medicina, Rio de Janeiro RJ, Brazil. Correspondence: Eliasz Engelhardt; Instituto de Neurologia Deolindo Couto - UFRJ; Av. Venceslau Braz, 95; 22290-140 Rio de Janeiro RJ, Brasil; E-mail: eliasz@centroin.com.br

Conflict of interest: There is no conflict of interest to declare.

Received 03 November 2014; Received in final form 07 January 2015; Accepted 27 January 2015. 
taking also part in governmental and educational committees. He became one of the most distinguished Brazilian scientist, with incontestable international recognition ${ }^{1,2,4}$.

Aristides Leão was an extraordinary person, with a very rich personal life, amidst his family and friends, besides manifold no-scientific and scientific extra-neurophysiological interests. Maranhão Filho and Vincent's paper on his personal life is worth reading ${ }^{1}$.

\section{THE DISCOVERY OF THE "SPREADING DEPRESSION"}

Once in Harvard (1941), Aristides Leão's was involved in a study on experimental epilepsy, conducted by Arturo Rosenblueth and Walter Cannon. They were analyzing the responses to electrical stimulation of the cortex of anesthetized rabbits, with electrodes placed on the cortical surface, and the changes were recorded by electrocorticography (ECoG). They agreed that some of the electrical epileptiform afterdischarges should be further studied by the newcomer. The analysis of the cycle of excitability of cortical neurons after the convulsive state, under supervision of Arturo Rosenblueth and Hallowell Davis, permitted him to identify a decrease of the excitability spreading in increasing circles around the initial focus, a phenomenon he named "spreading depression" (SD), the theme of his $\mathrm{PhD}$ thesis, the "Spreading depression of electrical activity in the cerebral cortex" (1943). Next year the study was published (1944), and soon the phenomenon was named after him ("Leão's wave" or "Leao's wave", or "spreading depression of Leão" $)^{1,2,3,5}$. In sequence he published another paper, in the same year, with focus on the vasodilatation accompanying $\mathrm{SD}^{6}$. Before leaving back to Brazil, he submitted, together with Robert S. Morison, the "Propagation of spreading cortical depression”, published in $1945^{7}$. Later, his first international paper developed in his Brazilian laboratory (1947) appeared ${ }^{8}$. These papers may be envisaged as seeminal (Box).

He kept producing numerous papers, mainly on his theme, the last one in 1992. His studies were very valued, and in the 70's his publications were responsible for the largest number of the citations received by the academics of the Brazilian Academy of Science ${ }^{2}$, it importance remaining in the medical literature until the present days (Figure 2).

In conclusion, following Leão's description of SD, in the 40's, numerous studies followed in the next decades for a better understanding of this and related phenomena, seen in normal and pathological conditions. The concept of spreading depolarization, a generic term for the whole spectrum of waves in the CNS, came in vogue. It was characterized by abrupt, near-complete sustained depolarization of neurons, related to massive ion translocation between intra- and extracellular space, neuronal swelling, distortion of dendritic spines, and glial depolarization. Such mechanism, preventing neurons to fire action potentials, cause as a consequence brain electrical silencing - the SD of Leão (1944), an epiphenomenon of spreading depolarization ${ }^{9}$. Here, the studies

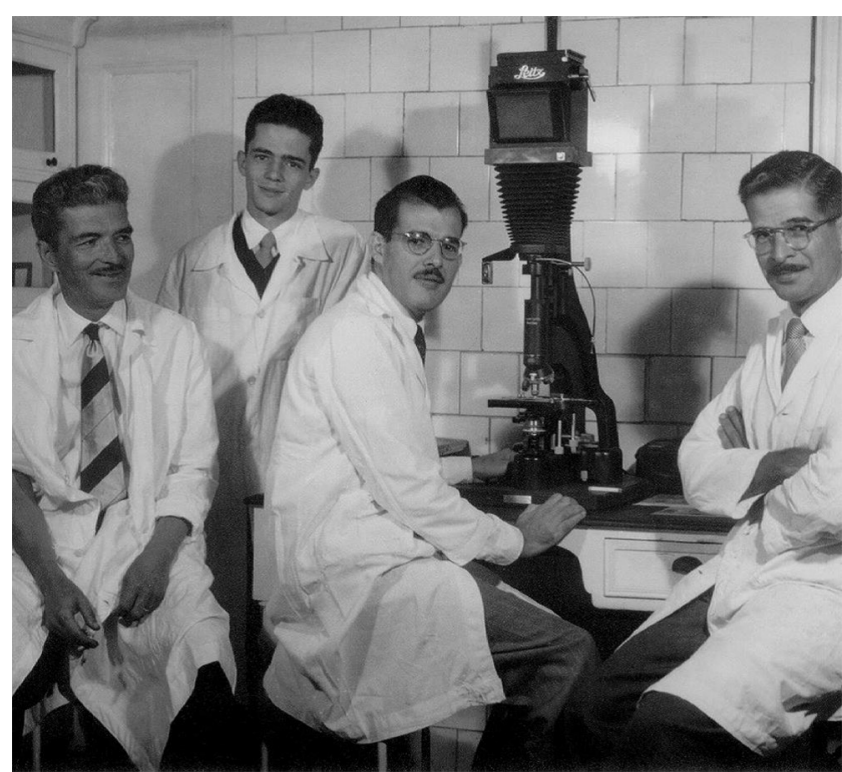

(Reproduction from the Archive of the Brazilian Academy of Science, with authorization [abc.org.br] [10-30-2014])

Figure 1. Laboratory in the IBCCF in the Faculdade Nacional de Medicina - Universidade do Brasil (FNM-UB). From left to right: Gustavo de Oliveira Castro, Gustavo Castro de Oliveira Filho, Antonio Moreira Couceiro, and Aristides Azevedo Pacheco Leão, after his return to Brazil.

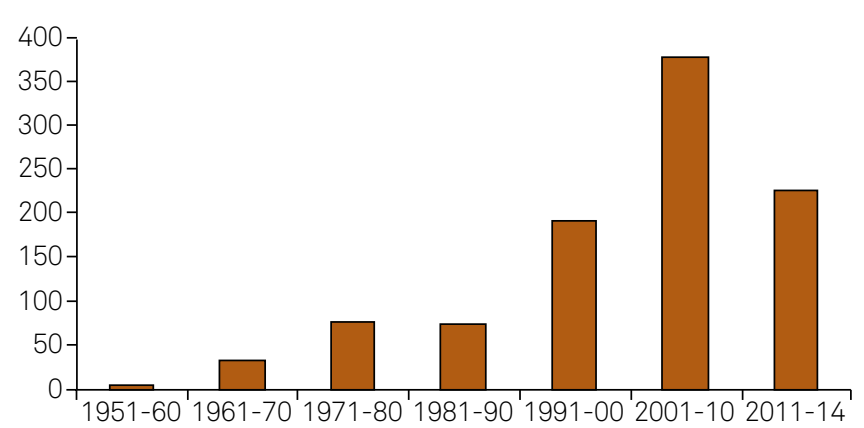

Figure 2. Spreading depression in the medical literature, from 1951 until now, search on Pubmed with the terms "spreading depression" or "cortical spreading depression" in the title or abstract (October, 2014).

advanced in relation to Leãos findings, by identifying the main electrophysiological occurrence, and its underpinnings, where SD continues as an important electrophysiological feature.

Since Leão's discovery, SD has been implicated by him, and soon by other authors, in migraine $e^{6,8}$. Although it has been known that ischemia could also trigger SD, as shown by Leão ${ }^{7,8}$, it was not until the 80's that recurrent SD-like depolarization waves were demonstrated in focal brain ischemia, which occurred as peri-infarct depolarizations (injury depolarizations, spreading depolarization), at the edge between the ischemic core and the penumbra rim. Such changes propagate often into tissue not attained by ischemia, where injurious metabolic and hemodynamic effects might be exerted, worsening the outcome. Thus, strong experimental and clinical evidence emerged to suggest that these cortical electrophysiological 
These studies, published in the Journal of Neurophysiology, were performed mainly in rabbits, under dial anesthesia, and pairs of electrodes were placed on their exposed cortical surface, one pair for stimulation, and the others, at increasing distance, for detetecting the electrographic changes recorded by ECoG.

$1^{\text {st }}$ paper (Leão, 1944) [“Spreading depression of activity in the cerebral cortex"]

Following the stimulation he observed often, instead seizure-like discharges, a flattening of the spontaneous ECoG waves. The activity was depressed first in the electrodes nearest to the stimulated area, and then slowly spreaded in all directions, affecting adjacent areas, eventually covering almost all the dorsolateral neocortex - the "spreading depression", a slow response that starting near the frontal pole might take more than 5 minutes to reach near the occipital pole. His experiments showed that the phenomenon was a cortico-cortical process 5 .

$2^{\text {nd }}$ paper (Leão, 1944) ["Pial circulation and spreading depression of activity in the cerebral cortex"]

Besides the SD, he described an accompanying vasodilatation - a vasodilatation and increased blood flow, in arteries and veins, correlated with local activity of the cortical neurons. Two mechanisms were suggested for such occurrence - release of a chemical vasodilator agent, or activation of local vasomotor nerves. Whatever the mechanism of the vasodilation, he commented, the marked increase in blood flow probably influences in turn the activity of the cortical neurons ${ }^{6}$.

$3^{\text {rd }}$ paper (Leão and Morison, 1945) [“Propagation of spreading cortical depression”]

Further investigation of the SD showed the attainment of the dorsolateral and medial-basal cortex, independent of subcortical connections and of the long association cortico-cortical tracts, the integrity of the corpus callosum for inter-hemispheric spread was needed. The destruction of the upper two layers of the cortex interrupted the spread. Changes in the permeability of the blood brain barrier to injected vital dyes, as ferrocyanide, trypan blue, and fuchsin, were not detected. According the investigators, the experiments leaved 'completely dark' the nature underlying the process of the cortical cells depression, but they were satisfied that "several obvious possibilities have been ruled out and attention directed to other paths of inquiry"

$4^{\text {th }}$ paper (Leão, 1947) [“Further observations on the spreading depression of activity in the cerebral cortex"]

The development of a specific electrical activity during the depression, which, when intense, closely resembled the "seizure pattern" of experimental epilepsy, incited to analyze the occurrence of a slow voltage variation - initially described as accompanying the SD, then considered as due to cortical anemia of short and prolonged duration, stating: "The results seem to indicate that in the SD of activity, a change of the same nature as one resulting from prolonged interruption of the circulation, occurs in the cerebral cortex,... suggesting that the negative voltage shifts of SD and of cortical ischemia are the result of 'some change of the same nature."'?

Box. Leão's seminal papers on spreading depression $n^{5,6,7,8}$.

phenomena are involved in the mechanisms of migraine aura, acute cerebrovascular diseases (including spreading ischemia), traumatic brain injury, transient global amnesia, epileptic seizures (including spreading convulsion), their pathophysiological characteristics offering novel therapeutic targets ${ }^{9,10}$.

\section{CONCLUSION}

The cortical SD and the accompanying vascular changes, revealed by Aristides Leão, triggered the study of important related phenomena. This knowledge allowed to better understanding the pathophysiology of several acute brain disorders, offering opportunities for early therapeutic interventions to change their outcome. This discovery granted him international scientific notoriety, and his seminal papers became classics in the field.

Aristides departed at the age of 79 years, after a very productive life, scientific and affective, leaving numerous friends, disciples and followers, in Brazil and abroad. One of them, Jan Bures, in a posthumous homage of the Academy of Science of the Czech Republic, wrote about the master (1994)" :I feel to be an old alumnus of Leão's invisible college, of the informal scientific community the members of which are scattered all over the world, but are nevertheless unified by the mysterious spell of a challenging problem, by the strong bonds formed in the joint pursuit of knowledge."

\section{References}

1. Maranhão Filho P, Vincent M. Professor Aristides Leão. Much more than spreading depression. Headache. 2009;49(1):110-6. http://dx.doi.org/10.1111/j.1526-4610.2008.01210.x

2. Gattass R. Aristides de Azevedo Pacheco Leão. In: Almeida DF, Souza W editores. Construtores do Instituto de Biofísica Carlos Chagas Filho. Rio de Janeiro: Corbã, 2013. p. 31-40.

3. Teive HA, Kowacs PA, Maranhão Filho P, Piovesan EJ, Werneck LC. Leao's cortical spreading depression: from experimental "artifact" to physiological principle. Neurology. 2005;65(9):1455-9.

4. Chagas Filho C. Um aprendiz de ciência. Rio de Janeiro: Fiocruz; 2000. Capítulo 5: Instituto de Biofísica Carlos Chagas Filho; p. 93-137.

5. Leão AAP. Spreading depression of activity in the cerebral cortex.J Neurophysiol. 1944;7(6):359-90
6. Leão AAP. Pial circulation and spreading depression of activity in the cerebral cortex. J Neurophysiol. 1944;7(6):391-6.

7. Leao AAP, Morison R. Propagation of spreading cortical depression.J Neurophysiol. 1945;8(1):33-45.

8. Leão AAP. Further observations on the spreading depression of activity in the cerebral cortex. J Neurophysiol. 1947;10(6):409-14.

9. Dreier JP. The role of spreading depression, spreading depolarization and spreading ischemia in neurological disease. Nat Med. 2011;17(4):439-47. http://dx.doi.org/10.1111/10.1038/nm.2333

10. Lauritzen M, Dreier JP, Fabricius M, Hartings JA, Graf R, Strong AJ. Clinical relevance of cortical spreading depression in neurological disorders: migraine, malignant stroke, subarachnoid and intracranial hemorrhage, and traumatic brain injury. J Cereb Blood Flow Metabol. 2011;31(1):17-35. 10.1038/jcbfm.2010.191 